\title{
Organization of $\mathrm{Ca}^{2+}$ stores in myeloid cells: association of SERCA2b and the type-1 inositol-1,4,5-trisphosphate receptor
}

\author{
Cécile J. FAVRE ${ }^{\star}$, Petra JERSTRÖM $\dagger$, Michelangelo FOTI ${ }^{\star}$, Olle STENDHAL $\dagger$, Elzbieta HUGGLER ${ }^{\star}$, Daniel P. LEW ${ }^{\star}$ and \\ Karl-Heinz KRAUSE*+ \\ *Division of Infectious Diseases, University Hospital CH-1211 Geneva-14, Switzerland and †Department of Medical Microbiology, Linköping University, \\ 58185 Linköping, Sweden
}

\begin{abstract}
In this study, we have analysed the relationship between $\mathrm{Ca}^{2+}$ pumps and $\mathrm{Ins}(1,4,5) P_{3}$-sensitive $\mathrm{Ca}^{2+}$ channels in myeloid cells. To study whether sarcoplasmic/endoplasmic reticulum $\mathrm{Ca}^{2+}$ ATPase (SERCA)-type $\mathrm{Ca}^{2+}$-ATPases are responsible for $\mathrm{Ca}^{2+}$ uptake into $\operatorname{Ins}(1,4,5) P_{3}$-sensitive $\mathrm{Ca}^{2+}$ stores, we used the three structurally unrelated inhibitors thapsigargin, 2,5-di-tbutylhydroquinone and cyclopiazonic acid. In HL-60 cells, all three compounds precluded formation of the phosphorylated intermediate of SERCA-type $\mathrm{Ca}^{2+}$-ATPases. They also decreased, in parallel, ATP-dependent $\mathrm{Ca}^{2+}$ accumulation and the amount of Ins $(1,4,5) P_{3}$-releasable $\mathrm{Ca}^{2+}$. Immunoblotting with subtype-directed antibodies demonstrated that HL-60 cells con-
\end{abstract}

tain the $\mathrm{Ca}^{2+}$ pump SERCA2 (subtype b), and the $\mathrm{Ca}^{2+}$-releasechannel type-1 Ins $(1,4,5) P_{3}$ receptor. In subcellular fractionation studies, SERCA2 and type-1 $\operatorname{Ins}(1,4,5) P_{3}$ receptor co-purified. Immunofluorescence studies demonstrated that both type-1 Ins $(1,4,5) P_{3}$ receptor and SERCA2 were evenly distributed throughout the cell in moving neutrophils. During phagocytosis both proteins translocated to the periphagosomal space. Taken together, our results suggest that in myeloid cells (i) SERCA-type $\mathrm{Ca}^{2+}$-ATPases function as $\mathrm{Ca}^{2+}$ pumps of $\operatorname{Ins}(1,4,5) P_{3}$-sensitive $\mathrm{Ca}^{2+}$ stores, and (ii) SERCA2 and type-1 Ins $(1,4,5) P_{3}$ receptor reside either in the same or two tightly associated subcellular compartments.

\section{INTRODUCTION}

Intracellular $\mathrm{Ca}^{2+}$ stores play an important role during cellular activation. $\mathrm{Ca}^{2+}$ release from these stores is mediated through two families of $\mathrm{Ca}^{2+}$ release channels: ryanodine receptors and Ins $(1,4,5) P_{3}$ receptors. In myeloid cells, type-1, type- 2 and type3 Ins $(1,4,5) P_{3}$ receptors have been identified [1-4], whereas there is no conclusive evidence for the presence of ryanodine receptors in these cells. $\mathrm{Ca}^{2+}$ accumulation into stores may be mediated through a family of Sarcoplasmic/Endoplasmic Reticulum $\mathbf{C a}^{2+}$ ATPases (SERCAs). SERCA1 and SERCA2a are exclusively expressed in muscle tissue. SERCA2b is ubiquitously distributed in non-muscle cells and is the major candidate to act as the $\mathrm{Ca}^{2+}$ pump of Ins $(1,4,5) P_{3}$-sensitive $\mathrm{Ca}^{2+}$ stores. In addition, SERCA3 is found in various non-muscle cell types (references for the distribution of SERCA-type $\mathrm{Ca}^{2+}$-ATPases include [5-11]). However, $\mathrm{Ca}^{2+}$-uptake mechanisms other than SERCA-type $\mathrm{Ca}^{2+}$ ATPases might participate in $\mathrm{Ca}^{2+}$ uptake into $\operatorname{Ins}(1,4,5) P_{3}$ sensitive $\mathrm{Ca}^{2+}$ stores: in some cellular systems, inhibitors of SERCA-type $\mathrm{Ca}^{2+}$-ATPases do not interfere with $\mathrm{Ca}^{2+}$ storage in Ins $(1,4,5) P_{3}$-sensitive $\mathrm{Ca}^{2+}$ stores [12,13], and $\mathrm{Ca}^{2+}$ uptake through a $\mathrm{H}^{+}$-dependent mechanism $[12,14]$ or through a $140 \mathrm{kDa}$ ' $\mathrm{Ca}^{2+}$-ATPase-like protein' [15] has been suggested.

Even in systems where the role of SERCA-type $\mathrm{Ca}^{2+}$-ATPase in intracellular $\mathrm{Ca}^{2+}$ accumulation is clearly established, $\mathrm{Ca}^{2+}$ release channels and $\mathrm{Ca}^{2+}$ pumps do not necessarily co-localize in the same intracellular compartment. The best studied example is the skeletal muscle sarcoplasmic reticulum (SR), where $\mathrm{Ca}^{2+}$ pumps are found in the longitudinal $\mathrm{SR}$, while $\mathrm{Ca}^{2+}$ release channels are found in the terminal cysternae. Accordingly, after subcellular fractionation of muscle homogenates $\mathrm{Ca}^{2+}$-ATPases and $\mathrm{Ca}^{2+}$ release channels are recovered in fractions of different densities. Separate sites for $\mathrm{Ca}^{2+}$ uptake and $\mathrm{Ca}^{2+}$ release have also been suggested by studies in several types of non-muscle cells [16-19].

In this study we demonstrate, in subcellular fractionation and immunofluorescence experiments, a close association between SERCA2b and the type- 1 Ins $(1,4,5) P_{3}$ receptor and, in functional experiments, the role of SERCA-type $\mathrm{Ca}^{2+}$-ATPases in the loading of Ins $(1,4,5) P_{3}$-sensitive $\mathrm{Ca}^{2+}$ stores.

\section{MATERIALS AND METHODS}

\section{Materials}

SDS/PAGE reagents were purchased from Bio-Rad. Alkaline phosphatase-coupled secondary antibodies, 5-bromo-4-chloro3-indolyl phosphate, Nitro Blue Tetrazolium, creatine phosphokinase, creatine phosphate, thapsigargin, cyclopiazonic acid, MgATP, ionomycin, digitonin, SDS, Hepes, $N$ (hydroxyethyl)ethylenediaminetriacetic acid (HEDTA), ethylene glycol bis( $\beta$-aminoethyl ether)- $N, N, N^{\prime}, N^{\prime}$-tetra-acetic acid (EGTA), antimycin A and oligomycin were obtained from Sigma (St. Louis, MO, U.S.A.). Di-isopropyl fluorophosphate (DFP) and 2,5-di-t-butylhydroquinone were from Fluka (Ronkonkoma, NY, U.S.A.), Ins $(1,4,5) P_{3}$ from L.C. Service Corp. (Woburn, MA, U.S.A.), ${ }^{45} \mathrm{Ca}^{2+}$ and $\left[{ }^{32} \mathrm{P}\right]$ ATP were purchased from DuPont de Nemours/New England Nuclear Inc. (Dreieich, Germany). ${ }^{35}$ S-labelled Protein A and ECL system were from Amersham International (Amersham, Bucks., U.K.). Acrylamide was from Kimberly Research (Manville, NJ, U.S.A.). All other reagents used were of analytical grade.

Abbreviations used: DFP, di-isopropyl fluorophosphate; HEDTA, $N$-(hydroxyethyl)ethylenediaminetriacetic acid; EGTA, ethylene glycol bis( $\beta$ aminoethyl ether)- $N, N, N^{\prime}, N^{\prime}$-tetra-acetic acid; SERCA, sarcoplasmic/endoplasmic reticulum $\mathrm{Ca}^{2+}$-ATPase; SR, sarcoplasmic reticulum.

\$ To whom correspondence should be addressed. 


\section{Purification of neutrophils, culture of HL-60 cells and subcellular fractionation procedures}

Neutrophils were purified from the blood of healthy donors as previously described [20]. HL-60 cells were grown as described previously [21]. To obtain homogenates, cells were disrupted by nitrogen cavitation followed by a low-speed centrifugation. To obtain a 'particulate fraction', homogenates were pelleted by a centrifugation of $160000 \mathrm{~g}$ for $60 \mathrm{~min}$. To obtain subcellular fractions, the homogenates were first separated by a discontinuous Percoll gradient. Three fractions, F1, F2, F3 (in order of decreasing density), were obtained. The light-density fraction of the Percoll gradient (F3) was further separated on a discontinuous sucrose gradient. Three fractions, S1, S2, S3 (in order of decreasing density), were obtained. For a more detailed description of the method see [21]. Protein concentrations were determined according to a modified Lowry procedure [22].

\section{SDS/PAGE and immunochemical analysis of HL-60 protein}

Proteins were separated by $3-12 \%$-acrylamide SDS/PAGE and transferred on to Immobilon poly(vinylidene difluoride) membrane (Millipore, U.S.A.) by standard methods. The transfers were blocked with PBS containing $0.05 \%$ Tween-20 and $0.5 \%$ non-fat dry milk prior to incubation with the primary antibody. ${ }^{35}$ S-Protein A, alkaline phosphatase-coupled or peroxidasecoupled secondary antibodies were used to develop immunoblots. Quantitative analysis was carried out using either a densitometer or a phosphoimager (Molecular Dynamics, U.S.A.).

\section{Antibodies used in this study}

Polyclonal antibodies against the $20 \mathrm{~N}$-terminal amino acids of SERCA2 $(\alpha$-Nterm SERCA2) and the $15 \mathrm{C}$-terminal amino acids of the type- $1 \operatorname{Ins}(1,4,5) P_{3}$ receptor $\left(\alpha\right.$-Cterm $\left.\operatorname{Ins} P_{3} \mathrm{R}\right)$ were raised in our laboratory using synthetic peptides as described previously [21]. A SERCA2b-specific antibody, raised against the 12 C-terminal amino acids of SERCA2b $(\alpha$-Cterm SERCA2b) was kindly provided by Dr. Franck Wuytack, Leuven, Belgium [7]. $\alpha$-Nterm SERCA2 did not stain any bands in immunoblots of skeletal muscle microsomes, suggesting that it did not recognize SERCA1 (results not shown). Based on the low sequence similarity of the N-terminus of SERCA2b and SERCA3, a crossreaction of $\alpha$-Nterm SERCA2 with SERCA3 appears unlikely. The specificity of the anti-SERCA2b antibodies has been established previously [7]. $\alpha$-Cterm $\operatorname{Ins} P_{3} \mathrm{R}$ did not stain any bands in immunoblots of skeletal muscle microsomes, suggesting that it did not recognize the skeletal muscle ryanodine receptor (results not shown). Given the low degree of similarity in the C-terminal region of $\operatorname{Ins}(1,4,5) P_{3}$ receptors, $\alpha$-Cterm $\operatorname{Ins} P_{3} \mathrm{R}$ is unlikely to cross-react with other $\operatorname{Ins}(1,4,5) P_{3}$ receptor isoforms. In addition, a polyclonal anti-peptide antibody raised against the same type1 Ins $(1,4,5) P_{3}$ receptor sequence as our antibody has been shown not to recognize type-2 $\operatorname{Ins}(1,4,5) P_{3}$ receptor [23].

\section{Formation of the phosphorylated intermediate}

SERCA phosphoenzyme levels were assessed using the method described by Heilmann et al. [24]. Particulate fractions or subcellular fractions of HL-60 cells $(0.25 \mathrm{mg}$ of protein $/ \mathrm{ml})$ were incubated at $4{ }^{\circ} \mathrm{C}$ with 5-10 $\mathrm{nM}\left[\gamma^{3}{ }^{32} \mathrm{P}\right] \mathrm{ATP}$ (specific radioactivity approx. $5000 \mathrm{Ci} / \mathrm{mmol}$ ) in a buffer containing $100 \mathrm{mM} \mathrm{KCl}$, $1 \mathrm{mM} \mathrm{MgCl}{ }_{2}, 50 \mu \mathrm{M} \mathrm{Ca}^{2+}, 20 \mathrm{mM}$ Hepes, $\mathrm{pH}$ 6.8. For control conditions (Figure 1A), $50 \mu \mathrm{M} \mathrm{Ca}^{2+}$ was omitted and $1 \mathrm{mM}$ EGTA was added. The reaction was stopped after $15 \mathrm{~s}$ by addition of 0.33 vol. of $40 \%$ (v/v) glycerol, $260 \mathrm{mM}$ Tris, $\mathrm{pH} 6.8$,
$4 \%$ 2-mercaptoethanol and $12 \%$ SDS; samples were immediately subjected to gel electrophoresis (10\% acrylamide). Phosphoproteins were visualized by autoradiography. The conditions chosen for the assessment of the phosphorylated intermediate (pH 6.8 in the sample buffer and $\mathrm{pH} 8.0$ in the running buffer) precluded detection of the plasma membrane $\mathrm{Ca}^{2+}$-ATPase $([25,26]$ see also below).

\section{Tryptic digestion of the particulate fraction from HL-60 cells}

Particulate fractions of HL-60 cells ( $4 \mathrm{mg}$ of protein $/ \mathrm{ml}$ ) were subjected to controlled tryptic digestion by incubation for $15 \mathrm{~min}$ at $37^{\circ} \mathrm{C}$ at the indicated protein/trypsin ratio in a buffer containing $100 \mathrm{mM} \mathrm{KCl}, 20 \mathrm{mM}$ Hepes, $\mathrm{pH} 6.8$, and $150 \mathrm{mM}$ sucrose [26]. The reaction was stopped by addition of soybean trypsin inhibitor [ratio of trypsin/inhibitor: 2:1 (w/w)] and placing the samples on ice. Assays for formation of phosphorylated intermediate were performed immediately as described above.

\section{${ }^{45} \mathrm{Ca}^{2+}$ technique}

For $\mathrm{Ca}^{2+}$-flux measurements, HL-60 homogenates $(250 \mu \mathrm{g} / \mathrm{ml})$ were preincubated for $10 \mathrm{~min}$ at $30^{\circ} \mathrm{C}$ in a buffer mimicking intracellular ionic conditions $\left(120 \mathrm{mM} \mathrm{KCl}, 1 \mathrm{mM} \mathrm{MgCl}_{2}\right.$, $25 \mathrm{mM}$ Hepes, $\mathrm{pH}$ 7.0) in the presence of an ATP-regenerating system (1 mM MgATP, $2.5 \mathrm{mM}$ creatine phosphate, 4 units $/ \mathrm{ml}$ creatine kinase $)$ and mitochondrial inhibitors $(0.2 \mu \mathrm{M}$ antimycin A and $1 \mu \mathrm{g} / \mathrm{ml}$ oligomycin). $\mathrm{Ca}^{2+}$ uptake was initiated by addition of $200 \mathrm{nCi} / \mathrm{ml}^{45} \mathrm{Ca}^{2+}$ and $20 \mu \mathrm{M}$ unlabelled $\mathrm{Ca}^{2+}$ (free cytosolic $\left.\left[\mathrm{Ca}^{2+}\right]_{\mathrm{c}}=200 \mathrm{nM}\right)$. Where indicated, $\mathrm{Ca}^{2+}$-ATPase inhibitors were added $3 \mathrm{~min}$ prior to initiation of $\mathrm{Ca}^{2+}$ uptake. ATPindependent $\mathrm{Ca}^{2+}$ accumulation was subtracted and did not exceed $5 \%$ of the total $\mathrm{Ca}^{2+}$ uptake. For the assessment of Ins $(1,4,5) P_{3}$-induced $\mathrm{Ca}^{2+}$ release, $5 \mu \mathrm{M} \operatorname{Ins}(1,4,5) P_{3}$ was added during the last $15 \mathrm{~s}$ of the $\mathrm{Ca}^{2+}$ uptake assay. At the indicated time, $100 \mu \mathrm{l}$ aliquots were taken in duplicate, transferred on to a $0.45 \mu \mathrm{m}$-pore-size filter (Millipore, HA type) and washed three times with $5 \mathrm{ml}$ of a buffer containing $120 \mathrm{mM} \mathrm{KCl}, 1 \mathrm{mM} \mathrm{LaCl}_{3}$ and $20 \mathrm{mM}$ Hepes, $\mathrm{pH}$ 7.0. Filters were placed in a vial containing a liquid scintillation mixture (Ultima Gold; Packard, Meriden, CT, U.S.A.) and the radioactivity was measured using a Packard 1900 TR scintillation counter.

\section{Immunocytochemistry and confocal microscopy}

Immunofluorescence of phagocytosing neutrophils was performed as described previously [20]. Neutrophils were allowed to adhere to glass coverslips and to phagocytose opsonized heatkilled yeast in a moist chamber $\left(37^{\circ} \mathrm{C}\right)$. After $10 \mathrm{~min}$, cells were fixed by a $60 \mathrm{~min}$ incubation with ice-cold paraformaldehyde ( $4 \%$ in PBS, pH 7.3). The slides were washed twice $(2 \times 10 \mathrm{~min})$ in PBS then permeabilized for $60 \mathrm{~s}$ in $0.3 \%$ Triton X-100 diluted in PBS (pH 7.3), and finally washed twice $(2 \times 10 \mathrm{~min})$ in PBS ( $\mathrm{pH}$ 7.3). To reduce non-specific binding of the primary antibodies, $50 \mu \mathrm{l}$ of normal pig immunoglobulin fraction $(10 \mathrm{mg} / \mathrm{ml}$; Dakopatts a/s, Copenhagen, Denmark) was added to each well on the slide and they were placed in a moist chamber at room temperature for $60 \mathrm{~min}$, or overnight at $4{ }^{\circ} \mathrm{C}$. The immunoglobulin fraction was 'poured' off the slides and the primary antibodies (described above), diluted 1:20 in PBS ( $\mathrm{pH}$ 7.6) with $1 \%(\mathrm{w} / \mathrm{v}) \mathrm{BSA}$, were added $(10 \mu \mathrm{l} /$ well). After $45 \mathrm{~min}$ incubation in a moist chamber at room temperature, the slides were washed three times $(3 \times 5 \mathrm{~min})$ in PBS-BSA $(1 \%)$. Then, $50 \mu \mathrm{l}$ of normal pig immunoglobulin fraction $(4 \mathrm{mg} / \mathrm{ml})$, in PBS-BSA $(1 \%)$, was 


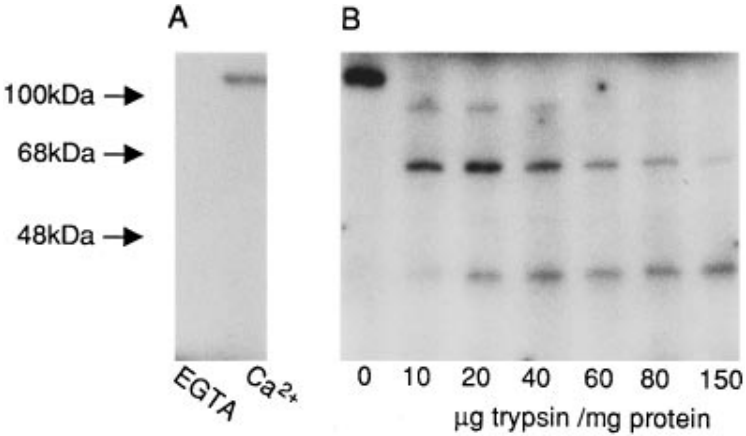

Figure 1 Characterization of a $100 \mathrm{kDa} \mathrm{Ca}{ }^{2+}$-ATPase in $\mathrm{HL}-60$ cells

Particulate fractions of $\mathrm{HL}-60$ cells $(0.25 \mathrm{mg} / \mathrm{ml})$ were incubated at $4{ }^{\circ} \mathrm{C}$ for $15 \mathrm{~min}$ in $100 \mathrm{mM}$ $\mathrm{KCl}, 1 \mathrm{mM} \mathrm{MgCl} 2,20 \mathrm{mM}$ Hepes, pH 6.8, in the presence of $1 \mathrm{mM}$ EGTA or $50 \mu \mathrm{M} \mathrm{Ca}^{2+}(\mathbf{A})$ and increasing concentrations of trypsin, $10 \mu \mathrm{g} / \mathrm{mg}$ of protein to $150 \mu \mathrm{g} / \mathrm{mg}$ of protein, in the presence of $50 \mu \mathrm{M} \mathrm{Ca}^{2+}$ (B). [ ${ }^{32}$ P]ATP (25 mCi/mg of protein) was added for $15 \mathrm{~s}$ and proteins were separated by SDS/PAGE, ${ }^{32}$ P-labelled protein was detected by autoradiography.

added to each well and the slides were incubated in a moist chamber for another $60 \mathrm{~min}$. Again the immunoglobulin fraction was poured off and $50 \mu \mathrm{l}$ of the secondary rhodamine-conjugated pig anti-(rabbit $\mathrm{IgG})$ antibody $(0.012 \mathrm{mg} / \mathrm{ml}$; Dakopatts a/s, Copenhagen, Denmark) in PBS-BSA $(1 \%)$ was added to each well, followed by a $45 \mathrm{~min}$ incubation. The slides were washed three times $(3 \times 5 \mathrm{~min})$ in PBS-BSA $(1 \%)$ and twice $(2 \times 5 \mathrm{~min})$ in PBS (pH 7.6). Finally the slides were mounted and examined.

\section{RESULTS}

When SERCA-type $\mathrm{Ca}^{2+}$-ATPases are incubated with $\left[{ }^{32} \mathrm{P}\right] \mathrm{ATP}$ in the presence of $\mathrm{Ca}^{2+}$, an approx. $100 \mathrm{kDa}$ phosphorylated intermediate can be visualized on autoradiograms of polyacrylamide gels (see, for example, [27]). To selectively visualize the SERCA, but not the plasma membrane $\mathrm{Ca}^{2+}$-ATPase, we took advantage of the different $\mathrm{pH}$ sensitivities of the respective phosphoproteins. The phosphorylated intermediate of the plasma membrane $\mathrm{Ca}^{2+}$-ATPase is stable only at low $\mathrm{pH}$ and separation by acidic SDS/PAGE is necessary for phosphoprotein detection [28]. In contrast, SERCA-type $\mathrm{Ca}^{2+}$-ATPases are readily detected at higher $\mathrm{pH}$ values using standard Läemmli-type SDS/PAGE $[24,26,27,29]$. Figure 1(A) shows that HL-60 cells contain SERCA-type $\mathrm{Ca}^{2+}$-ATPases which undergo $\mathrm{Ca}^{2+}$-dependent formation of an approx. $100 \mathrm{kDa}$ phosphorylated intermediate. Owing to their large intramembrane domains, SERCA-type $\mathrm{Ca}^{2+}$ pumps show a typical pattern of limited tryptic digestion. Formation of 55 and $30 \mathrm{kDa}$ tryptic fragments that are still able to catalyse the autophosphorylation reaction are observed for SERCA1 and $2[25,30]$. In contrast, formation of an approx. $80 \mathrm{kDa}$ tryptic fragment is observed for SERCA3 [30,31]. After limited tryptic digestion of HL-60 particulate fractions, fragments of approx. 80, 55 and $30 \mathrm{kDa}$ could be observed (Figure 1B). The 55 and $30 \mathrm{kDa}$ fragments most likely reflect the presence of SERCA2b (see below). The additional presence of an $80 \mathrm{kDa}$ band is consistent with recent studies that suggest the expression of SERCA3 in HL-60 cells [11].

\section{$\mathrm{Ca}^{2+}$-ATPase inhibitors preclude formation of the phosphorylated intermediate, ATP-dependent $\mathrm{Ca}^{2+}$ uptake and Ins $(1,4,5) P_{3}$-induced $\mathrm{Ca}^{2+}$ release}

We have previously reported that three structurally unrelated compounds, thapsigargin, cyclopiazonic acid and 2,5-di-t-

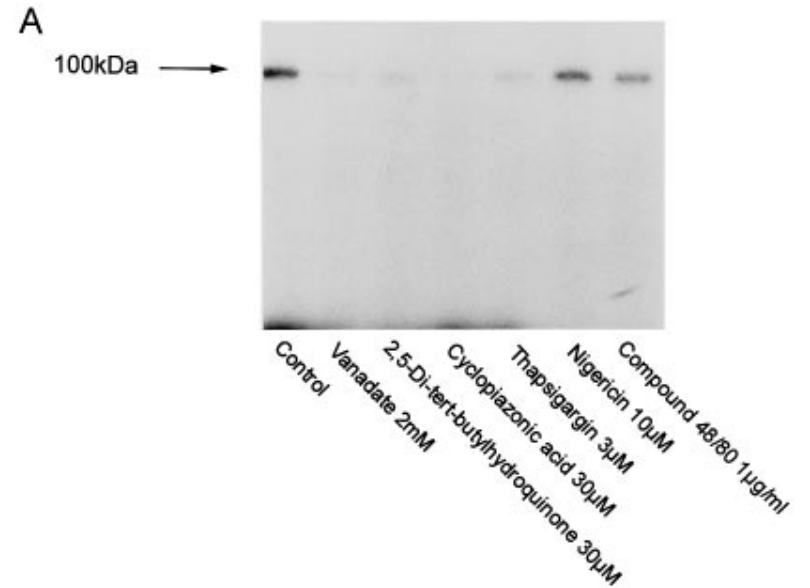

Figure 2 Inhibition of formation of phosphorylated intermediate by various $\mathrm{Ca}^{2+}$-ATPase inhibitors

Particulate fraction of $\mathrm{HL}-60$ cells was preincubated for 15 min with the indicated concentrations of vanadate, cyclopiazonic acid, 2,5-di-t-butylhydroquinone, thapsigargin, nigericin, or compound 48/80. The fractions were then assayed for the formation of a $\mathrm{Ca}^{2+}$-ATPase phosphorylated intermediate as described in the Materials and methods section. The results are representative of three independent experiments.

butylhydroquinone effectively deplete intracellular $\mathrm{Ca}^{2+}$ stores in intact HL-60 cells $[32,33]$. To study whether these inhibitors block SERCA-type $\mathrm{Ca}^{2+}$ pumps in HL-60 cells, we investigated their effects on formation of the phosphorylated intermediate. As shown in Figure 2, thapsigargin, cyclopiazonic acid and 2,5-di-tbutylhydroquinone inhibited formation of the phosphorylated intermediate. An inhibition was also observed with the nonspecific ATPase inhibitor vanadate, while control substances (nigericin, compound 48/80) had no relevant effects.

To study whether the $\mathrm{Ca}^{2+}$-ATPases inhibited through thapsigargin, cyclopiazonic acid and 2,5-di-t-butylhydroquinone might be responsible for $\mathrm{Ca}^{2+}$ uptake into $\operatorname{Ins}(1,4,5) P_{3}$-sensitive pools, we studied the effect of the inhibitors on ATP-dependent $\mathrm{Ca}^{2+}$ uptake and the amount of $\operatorname{Ins}(1,4,5) P_{3}$-releasable $\mathrm{Ca}^{2+}$ in HL-60 homogenates. Thapsigargin, cyclopiazonic acid, 2,5-di-tbutylhydroquinone, and vanadate led to a dose-dependent inhibition of ATP-dependent $\mathrm{Ca}^{2+}$ accumulation (Figure 3). The amount of Ins $(1,4,5) P_{3}$-releasable $\mathrm{Ca}^{2+}$ was diminished with a virtually identical potency by the four different compounds, suggesting that (i) there is no pharmacological difference between the $\mathrm{Ca}^{2+}$ pumps responsible for the all-over $\mathrm{Ca}^{2+}$ uptake and those responsible for $\mathrm{Ca}^{2+}$ uptake into $\operatorname{Ins}(1,4,5) P_{3}$-sensitive $\mathrm{Ca}^{2+}$ stores, and (ii) SERCA-type $\mathrm{Ca}^{2+}$ pumps are responsible for $\mathrm{Ca}^{2+}$ uptake into $\operatorname{Ins}(1,4,5) P_{3}$-sensitive $\mathrm{Ca}^{2+}$ stores. This is in accordance with previously published results in intact HL-60 cells, where a dose-dependent inhibition of agonist-induced $\mathrm{Ca}^{2+}$ release by thapsigargin, cyclopiazonic acid and 2,5-di-tbutylhydroquinone was observed [32]. However, the $\mathrm{IC}_{50}$ for depletion of $\mathrm{Ca}^{2+}$ stores in intact cells was about 40 -fold higher for cyclopiazonic acid $(2.8 \mu \mathrm{M})$ and 2,5-di-t-butylhydroquinone $(2.6 \mu \mathrm{M})$, but approx. 20 -fold lower for thapsigargin $(3.8 \mathrm{nM})$. These differences might reflect the fact that thapsigargin is a very hydrophobic compound (i) that penetrates freely into intact cells, and (ii) whose biological effects would be better described as inhibitor/phospholipid ratio than as concentration in an aqueous solution. Because of the very high affinity of thapsigargin for SERCA, it is also possible that the different $\mathrm{IC}_{50}$ in cells compared 

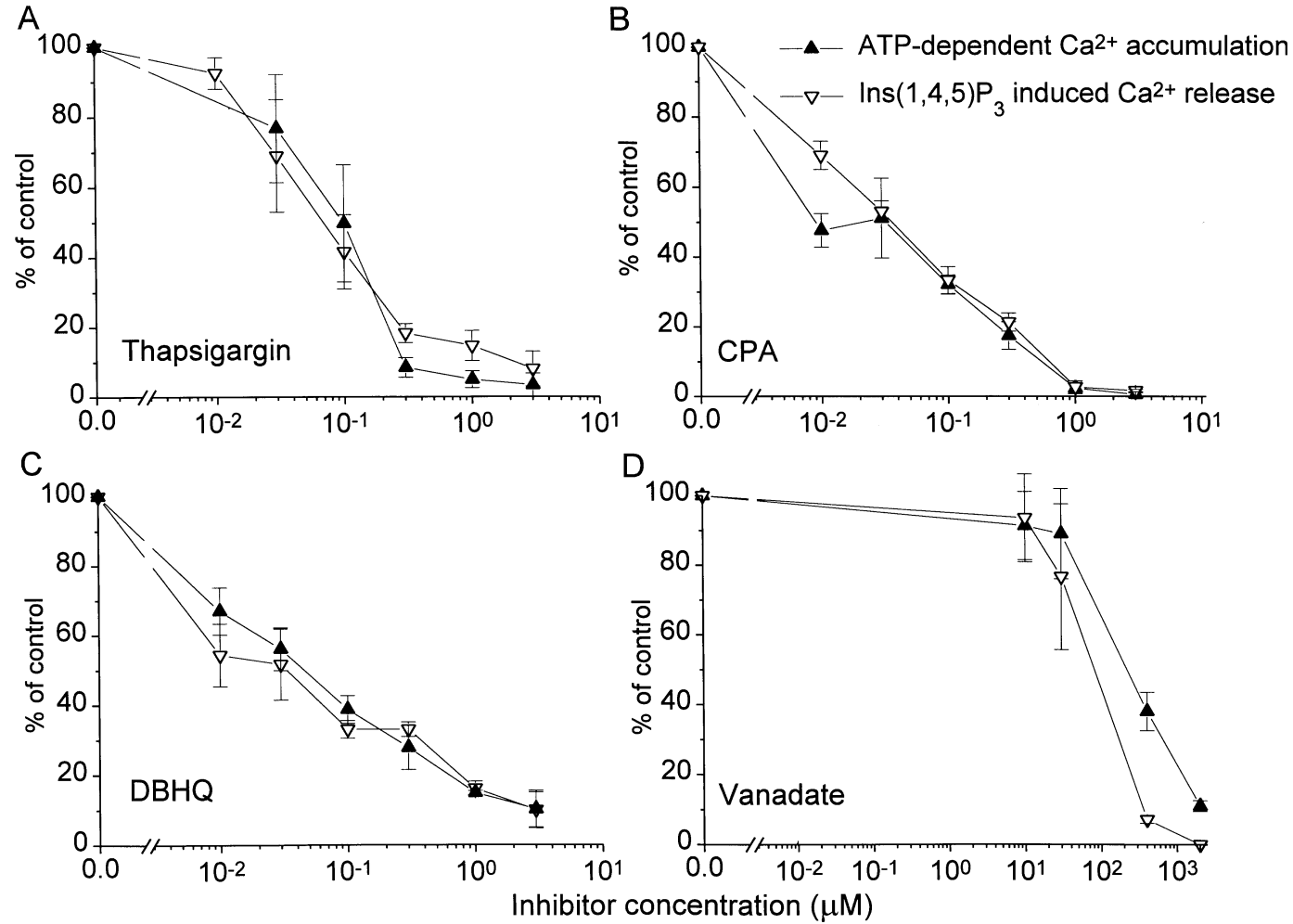

\section{Figure 3 Effect of SERCA inhibitors on ATP-dependent $\mathrm{Ca}^{2+}$ accumulation and amount of Ins $(1,4,5) P_{3}$-releasable $\mathrm{Ca}^{2+}$}

HL-60 homogenates were, after a 3 min preincubation with the respective inhibitor at the indicated concentration, allowed to accumulate ${ }^{45} \mathrm{Ca}^{2+}$ for 10 min in the presence of ATP. ATP-dependent $\mathrm{Ca}^{2+}$ accumulation $(\boldsymbol{\Lambda})$ and amount of $\mathrm{Ca}^{2+}$ that could be released by $5 \mu \mathrm{M} \operatorname{Ins}(1,4,5) P_{3}(\nabla)$ are shown as a function of the inhibitor concentration. The values were normalized as follows: the $\mathrm{Ca}^{2+}$ content of homogenates loaded in the absence of $\mathrm{Ca}^{2+}$-ATPase inhibitors (2.5 to $3.2 \mathrm{nmol}$ of $\mathrm{Ca}^{2+} / \mathrm{mg}$ of protein) was defined as $100 \%$. The amount of Ca ${ }^{2+}$ released by $5 \mu \mathrm{M} \mathrm{Ins}(1,4,5) P_{3}$ in the absence of $\mathrm{Ca}^{2+}$-ATPase inhibitors (1.4 to $1.6 \mathrm{nmol}$ of $\mathrm{Ca}^{2+} / \mathrm{mg}$ of protein) was defined as $100 \%$. IC $\mathrm{C}_{50}$ values were $68.5 \pm 29.3 \mathrm{nM}, 37.8 \pm 2.2 \mathrm{nM}, 30.3 \pm 17.0 \mathrm{nM}$, and $177.3 \pm 30.1 \mu \mathrm{M}$, for ATP-dependent $\mathrm{Ca}^{2+}$ accumulation and $91.7 \pm 37.8 \mathrm{nM}, 38.1 \pm 10.3 \mathrm{nM}, 46.8 \pm 15.7 \mathrm{nM}$, and $61.5 \pm 36.2 \mu \mathrm{M}$ for Ins $(1,4,5) P_{3}$-induced $\mathrm{Ca}^{2+}$ release, for thapsigargin, cyclopiazonic acid (CPA), 2,5-di-t-butylhydroquinone (DBHQ) and vanadate respectively. Results are given as means \pm S.E.M. of three independent experiments performed in duplicate.

A

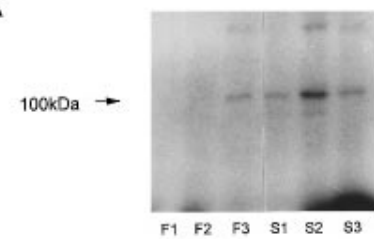

C

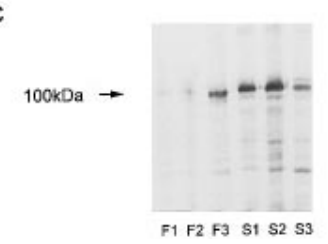

B

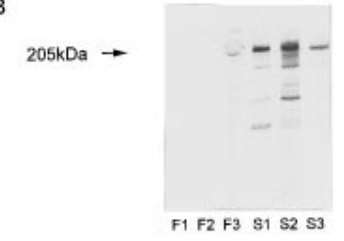

D

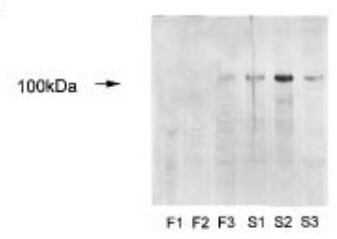

Figure 4 Distribution of SERCA2b and type-1 Ins $(1,4,5) P_{3}$ receptor in subcellular fractions of HL-60 cells

HL-60 cell homogenates were separated by a discontinuous Percoll gradient. Three subcellular fractions were obtained and are referred to, in order of decreasing density, as F1, F2 and F3. The light-density fraction F3 was further separated by a discontinuous sucrose gradient leading to another three subcellular fractions S1, S2 and S3 (referred to in order of decreasing density). (A) $\mathrm{Ca}^{2+}$-dependent formation of a phosphorylated intermediate; (B, C and D) immunoblots using antibodies against type-1 Ins $(1,4,5) P_{3}$ receptor, SERCA2b and SERCA2 respectively. The antibodies are described in the Materials and methods section. Blots are representative from two to three independent experiments performed in duplicates.

with homogenate may simply be related to the relative amounts of SERCA in the two preparations.

\section{Distribution of SERCA and Ins $(1,4,5) P_{3}$ receptor in subcellular fractions of HL-60 cells}

We have previously developed a subcellular fractionation procedure to obtain subcellular fractions highly enriched in inositoltrisphosphate binding [21]. The procedure consists of a nitrogen cavitation, followed by Percoll- and sucrose-density gradients. As compared with the starting homogenate, Ins $(1,4,5) P_{3}$ binding and calreticulin content were enriched approx. 7-fold through the Percoll gradient (F3) and further enriched to approx. 25-fold through the sucrose gradient (S2).

In this study we have used the same fractions to analyse the subcellular distribution of the phosphorylated $\mathrm{Ca}^{2+}$-ATPase intermediate (Figure 4A), and SERCA2 (Figures 4C and 4D) and type- $1 \mathrm{Ins}(1,4,5) P_{3}$ receptor (Figure $\left.4 \mathrm{~B}\right)$. To obtain statistics, we normalized the specific protein content of the different fractions with respect to the most intensely stained fraction (S2 of the sucrose gradient), which was defined as 100 (Table 1). Clearly, SERCA2 and type- $1 \operatorname{Ins}(1,4,5) P_{3}$ receptor showed a very similar distribution within the different fractions. There appeared to be a slightly different distribution of the phosphorylated intermediate and SERCA2 (Table 1, fraction S1). As the phosphorylated intermediate signal comes from both, SERCA2 and 
Table 1 Relative content of phosphorylated intermediate, SERCA2b, type1 Ins $(1,4,5) P_{3}$ receptor, and Ins $(1,4,5) P_{3}$-binding sites in subcellular fractions

Data shown in this Table represent statistics of a quantification of experiments shown in Figure 4 (columns 1, 2 and 3) or results from a previous study (column 4; [21]). Immunoblots and autoradiograms were quantified as described in the Materials and methods section. The protein content of the various fractions were normalized with respect to the most intensely stained fraction (S2 of the sucrose gradient), which was defined as 100. Data are mean \pm S.E.M. [SERCA2b and Ins $(1,4,5) P_{3}$ binding; $n=3$ and $n=4$, respectively] and mean \pm range [phosphorylated intermediate and type- $1 \operatorname{Ins}(1,4,5) P_{3}$ receptor; $n=2$ ]; all experiments were performed in duplicate.

\begin{tabular}{ccccc}
\hline & $\begin{array}{c}\text { Phosphorylated } \\
\text { intermediate (\%) }\end{array}$ & SERCA2b (\%) & $\begin{array}{l}\text { Type-1 Ins(1,4,5) } P_{3} \\
\text { receptor }(\%)\end{array}$ & $\begin{array}{l}\text { Ins(1,4,5) } P_{3} \\
\text { binding (\%) }\end{array}$ \\
\hline F1 & $3 \pm 3$ & $2 \pm 2$ & $6 \pm 8$ & $1 \pm 1$ \\
F2 & $7 \pm 7$ & $3.5 \pm 3.5$ & $3.5 \pm 5$ & $2 \pm 1$ \\
F3 & $31 \pm 11$ & $33.5 \pm 18$ & $28 \pm 24$ & $24 \pm 3$ \\
S1 & $27 \pm 4$ & $66 \pm 7$ & $63 \pm 5$ & $83 \pm 20$ \\
S2 & 100 & 100 & 100 & 100 \\
S3 & $32 \pm 1$ & $31 \pm 7$ & $38 \pm 7$ & $20 \pm 11$ \\
& & & & \\
\hline
\end{tabular}

SERCA3, this might indicate a partially different subcellular distribution of the two $\mathrm{Ca}^{2+}$-ATPases. For comparison, we have also added previous results [21], showing $\operatorname{Ins}(1,4,5) P_{3}$ binding in these fractions. The distribution of $\operatorname{Ins}(1,4,5) P_{3}$ binding was very similar to the distribution of the type- $1 \operatorname{Ins}(1,4,5) P_{3}$ receptor.

\section{Immunofluorescence of Ins(1,4,5) $P_{3}$ receptor and $\mathrm{Ca}^{2+}$-ATPase during chemotaxis and phagocytosis}

We have recently shown that translocation of calreticulin and SERCA2 to the periphagosomal space occurs during phagocytosis in human neutrophils, suggesting a transport of intracellular $\mathrm{Ca}^{2+}$ stores to their site of action [34]. To investigate whether this $\mathrm{Ca}^{2+}$ store translocation includes $\operatorname{Ins}(1,4,5) P_{3}$ sensitive $\mathrm{Ca}^{2+}$ stores, we performed confocal immunofluorescence studies using the antibody against the type- $1 \operatorname{Ins}(1,4,5) P_{3}$ receptor and against SERCA2. Immunofluorescence staining of adherent, non-phagocytosing neutrophils showed an equal distribution of both SERCA2 and type-1 Ins(1,4,5) $P_{3}$ receptor throughout the entire cell (Figures 5A and 5C). During phagocytosis, both SERCA2 and type-1 $\operatorname{Ins}(1,4,5) P_{3}$ receptor showed a similar translocation towards the periphagosomal space (Figures $5 \mathrm{~B}$ and $5 \mathrm{D})$.

\section{DISCUSSION}

Our results demonstrate a close association between SERCA2 and the type- 1 Ins $(1,4,5) P_{3}$ receptor: (i) inhibition of SERCAtype $\mathrm{Ca}^{2+}$ pumps leads to an inhibition of $\operatorname{Ins}(1,4,5) P_{3}$-induced $\mathrm{Ca}^{2+}$ release with identical dose-inhibition curves; (ii) an ex-
A

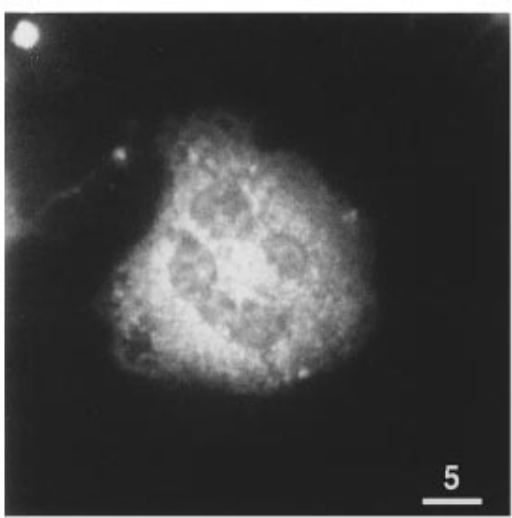

B

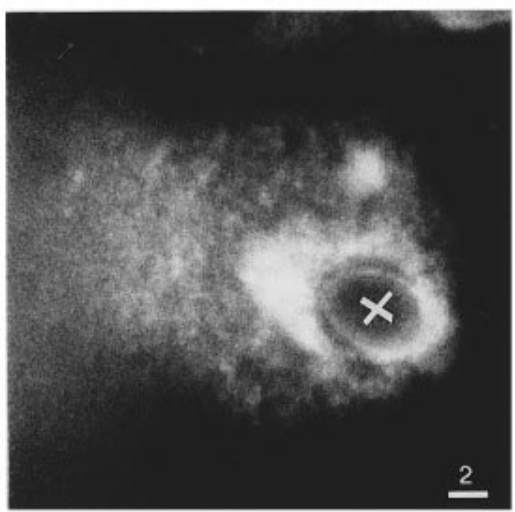

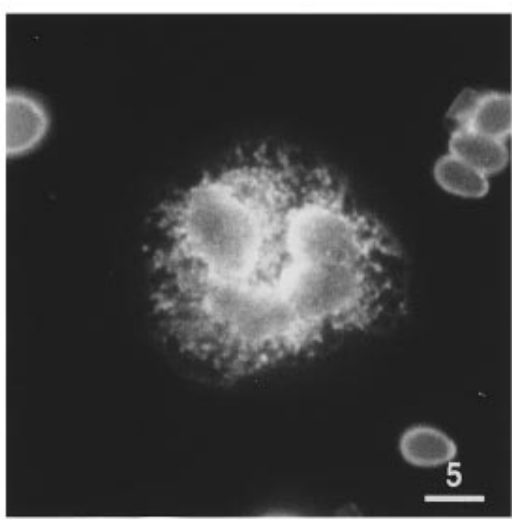

$\mathrm{C}$

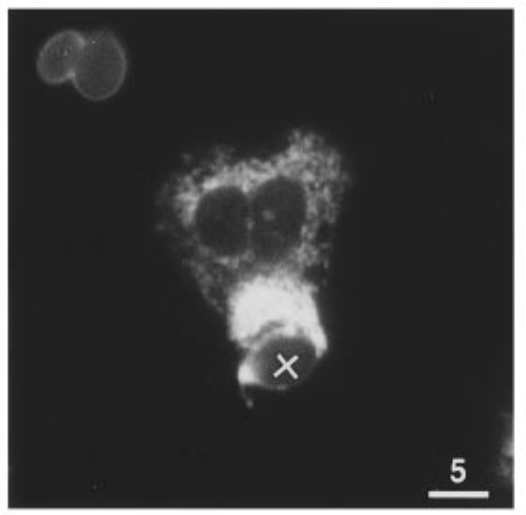

D

\section{Figure 5 Distribution of $\mathrm{Ca}^{2+}$-ATPase and $\operatorname{Ins}(1,4,5) P_{3}$ receptor in resting and phagocytosing neutrophils}

Non-phagocytosing $(\mathbf{A}$ and $\mathbf{C})$ and phagocytosing $(\mathbf{B}$ and $\mathbf{D})$ adherent neutrophils were permeabilized with $0.3 \%$ Triton and incubated either with antibodies against the type-1 Ins $(1,4,5) P_{3}$ receptor $(\mathbf{A}$ and $\mathbf{B})$ or with antibodies against SERCA2 (C and $\mathbf{D})$. Each panel shows rhodamine fluorescence from 1- $\mu$ m-thick confocal serial sections through the centre. The white cross indicates the position of phagocytosed yeast particles. The numbers above the scale bars indicate their length $(\mu \mathrm{m})$. The examples shown are representative of the cells from a total of three experiments. In control experiments without primary antibody, only a faint background fluorescence and no periphagosomal enrichment was observed. 
tensive subcellular purification procedure yielded a copurification of both proteins; and (iii) both proteins showed the same immunofluorescence pattern during chemotaxis and phagocytosis of neutrophils.

The $\mathrm{Ca}^{2+}$-ATPase inhibitors thapsigargin, cyclopiazonic acid and 2,5-di-t-butylhydroquinone at appropriate concentrations are relatively selective for SERCA-type $\mathrm{Ca}^{2+}$-ATPases, but do not enable us to distinguish between SERCA subtypes [35,36]. Thus, the functional data presented in Figure 3 do not provide evidence with respect to the involved SERCA and $\operatorname{Ins}(1,4,5) P_{3}$ receptor isoforms. However, the data clearly demonstrate the function of SERCA-type $\mathrm{Ca}^{2+}$-ATPases as $\mathrm{Ca}^{2+}$ pumps of Ins $(1,4,5) P_{3}$-sensitive $\mathrm{Ca}^{2+}$ stores in myeloid cells. This is particularly relevant with respect to reports from other cell types, that suggest $\mathrm{Ca}^{2+}$ uptake into $\mathrm{Ins}(1,4,5) P_{3}$-sensitive $\mathrm{Ca}^{2+}$ stores through SERCA-unrelated mechanisms [12-15].

Previous studies in other non-muscle cells have raised the possibility that sites for $\mathrm{Ca}^{2+}$ uptake and for $\mathrm{Ca}^{2+}$ release might be localized in separate intracellular compartments [16-19]. The endoplasmic reticulum network, thought to contain intracellular $\mathrm{Ca}^{2+}$ stores, is broken into so-called microsomes during cell homogenization. Proteins that are differentially located within this network, should therefore be differentially recovered after subcellular fractionation. We have previously described [21] such a separation of $\mathrm{Ca}^{2+}$ store markers [calreticulin and $\operatorname{Ins}(1,4,5) P_{3}$ binding] from other endoplasmic reticulum proteins that are unrelated to its $\mathrm{Ca}^{2+}$ store function (sulphatase $\mathrm{C}$ and cytochrome $c$ reductase). Thus, our gradients are able to detect endoplasmic reticulum subfractions. However, in the present study, SERCA2 and type-1 Ins $(1,4,5) P_{3}$ receptor show a virtually identical subcellular distribution. Thus, our results strongly suggest that in HL-60 cells, SERCA2 and type- 1 Ins $(1,4,5) P_{3}$ receptor reside within the same, or within closely associated compartments.

Changes in the subcellular localization of the $\operatorname{Ins}(1,4,5) P_{3}$ receptor in response to cellular activation has been observed in $X$. laevis oocytes [37] and in lymphocytes [38]. Previous studies from our group revealed a dynamic redistribution of the $\mathrm{Ca}^{2+}$ store markers calreticulin and SERCA2 during phagocytosis in human neutrophils [34]. In this study we show that, in phagocytosing neutrophils, the type- $1 \operatorname{Ins}(1,4,5) P_{3}$ receptor is similarly translocated to the periphagosomal space. Thus, it appears that entire Ins $(1,4,5) P_{3}$-sensitive $\mathrm{Ca}^{2+}$ stores, and not only $\mathrm{Ca}^{2+}$ ATPase and calreticulin are translocated. This adds weight to the concept that the observed phenomenon corresponds indeed to translocation of organelles, rather than individual proteins. The parallel translocation of SERCA2 and type- $1 \operatorname{Ins}(1,4,5) P_{3}$ receptor clearly argues in favour of a co-localization of the two proteins on the translocated organelles.

However, myeloid cells do not only contain SERCA2 and type-1 Ins(1,4,5) $P_{3}$ receptor, but also SERCA3 ([11]; see also Figure 1), type-2 $\operatorname{Ins}(1,4,5) P_{3}$ receptor and type-3 $\operatorname{Ins}(1,4,5) P_{3}$ receptor [2-4]. Although it is possible that these proteins localize to the same type of $\mathrm{Ca}^{2+}$ store, other possibilities have to be taken into consideration: distinct SERCA3/type-3 $\operatorname{Ins}(1,4,5) P_{3}$ receptor $\mathrm{Ca}^{2+}$ stores might exist or a separation of $\mathrm{Ca}^{2+}$ release and $\mathrm{Ca}^{2+}$ uptake sites might be present on the level of these proteins.

This research was supported by the grants from the Swiss National Foundation (32 30161.90), from the Carlos-and-Elsie-de-Reuter-Foundation, Geneva, from the Sandoz foundation, Basel, from the Ernst-and-Lucie-Schmidheiny-Foundation, Geneva, from the Société Académique, Geneva, and from the Swedish Medical Research Council. We thank Dr. Frank Wuytack for providing the antibody against the SERCA2b Cterminal.

\section{REFERENCES}

1 Yamada, N., Makino, Y., Clark, R. A., Pearson, D. W., Mattei, M.-G., Guénet, J.-L., Ohama, E., Fujino, I., Miyawaki, A., Furuichi, T. and Mikoshiba, K. (1994) Biochem. J. 302, 781-790

2 Sugiyama, T., Furuya, A., Monkawa, T., Yamamoto Hino, M., Satoh, S., Ohmori, K., Miyawaki, A., Hanai, N., Mikoshiba, K. and Hasegawa, M. (1994) FEBS Lett. 354, 149-154

3 Sugiyama, T., Yamamoto Hino, M., Miyawaki, A., Furuichi, T., Mikoshiba, K. and Hasegawa, M. (1994) FEBS Lett. 349, 191-196

4 Yamamoto Hino, M., Sugiyama, T., Hikichi, K., Mattei, M.-G., Hasegawa, K., Sekine, S., Sakurada, K., Miyawaki, A., Furuichi, T., Hasegawa, M. and Mikoshiba, K. (1994) Receptors-Channels 2, 9-22

5 Brandl, C. J., Green, N. M., Korczak, B. and MacLennan, D. H. (1986) Cell 44 597-607

6 Anger, M., Samuel, J.-L., Marotte, F., Wuytack, F., Rappaport, L. and Lompré, A.-M. (1993) FEBS Lett. 334, 45-48

7 Wuytack, F., Eggermont, J. A., Raeymaekers, L., Plessers, L. and Casteels, R. (1989) Biochem. J. 264, 765-769

8 Burk, S. E., Lytton, J., MacLennan, D. H. and Shull, G. E. (1989) J. Biol. Chem. 264, 18561-18568

9 Gunteski-Hamblin, A.-M., Greeb, J. and Shull, G. E. (1988) J. Biol. Chem. 263, 15032-15040

10 Lytton, J. and MacLennan, D. H. (1988) J. Biol. Chem. 263, 15024-15031

11 Wuytack, F., Dode, L., Baba-Aissa, F. and Raeymaekers, L. (1995) Biosci. Rep., 15, 299-306

12 Thevenod, F. and Schulz, I. (1988) Am. J. Physiol. 255, G1-G40

13 Robinson, I. M., Cheek, T. R. and Burgoyne, R. D. (1992) Biochem. J. 288, 457-463

14 Bode, H. P., Eder, B. and Trautmann, M. (1994) Eur. J. Biochem. 222, 869-877

15 Burgoyne, R. D., Cheek, T. R., Morgan, A., O'Sullivan, A. J., Moreton, R. B., Berridge, M. J., Mata, A. M., Coyler, J., Lee, A. G. and East, J. M. (1989) Nature (London) 343, 72-74

16 Villa, A., Sharp, A. H., Racchetti, G., Podini, P., Bole, D. G., Dunn, W. A., Pozzan, T., Snyder, S. H. and Meldolesi, J. (1992) Neuroscience 49, 467-477

17 Nori, A., Villa, A., Podini, P., Witcher, D. R. and Volpe, P. (1993) Biochem. J. 291, 199-204

18 Rossier, M. F. and Putney, J. W. J. (1991) Trends Neurosci. 14, 310-314

19 Islam, M. S. and Berggren, P.-0. (1993) Biochem. J. 293, 423-429

20 Jaconi, M. E. E., Lew, D. P., Carpentier, J. L., Magnusson, K. E., Sjogren, M. and Stendahl, 0. (1990) J. Cell Biol. 110, 1555-1564

21 Van Delden, C., Favre, C. J., Spat, A., Cerny, E., Krause, K. H. and Lew, D. P. (1992) Biochem. J. 281, 651-656

22 Peterson, G. L. (1977) Anal. Biochem. 83, 346-356

23 Parys, J. B., De Smedt, H., Missiaen, L., Bootman, M. D., Sienaert, I. and Casteels, R. (1995) Cell Calcium 17, 239-249

24 Heilmann, C., Spamer, C. and Gerok, W. (1983) Biochem. Biophys. Res. Commun. 114, 584-592

25 Stewart, P. S., MacLennan, D. H. and Shamoo, A. E. (1976) J. Biol. Chem. 251, 712-719

26 Spamer, C., Heilman, C. and Gerok, W. (1987) J. Biol. Chem. 262, 7782-7789

27 Heimann, P., Spamer, C. and Gerok, W. (1984) J. Biol. Chem. 259, 11139-11144

28 Sarkadi, B., Enyedi, A., Földes-Papp, Z. and Gardos, G. (1986) J. Biol. Chem. 261, 9552-9557

29 Heilmann, C., Spamer, C. and Gerok, W. (1985) J. Biol. Chem. 260, 788-794

30 Kovacs, T., Corvazier, E., Papp, B., Magnier, C., Bredoux, R., Enyedi, A., Sarkadi, B. and Enouf, J. (1994) J. Biol. Chem. 269, 6177-6184

31 Wuytack, F., Papp, B., Verboomen, H., Raeymaekers, L., Dode, L., Bobe, R., Enouf, J., Bokkala, S., Authi, K. S. and Casteels, R. (1994) J. Biol. Chem. 269, 1410-1416

32 Demaurex, N., Lew, D. P. and Krause, K. H. (1992) J. Biol. Chem. 267, 2318-2324

33 Favre, C. J., Lew, D. P. and Krause, K.-H. (1994) Biochem. J. 302, 155-162

34 Stendahl, O., Krause, K. H., Krischer, J., Jerström, P., Theler, J. M., Clark, R. A., Carpentier, J. L. and Lew, D. P. (1994) Science 265, 1439-1441

35 Lytton, J., Westlin, M. and Hanley, M. R. (1991) J. Biol. Chem. 266, 17067-17071

36 Thastrup, O., Cullen, P. J., Drobak, B. K., Hanley, M. R. and Dawson, A. P. (1990) Proc. Natl. Acad. Sci. U.S.A. 87, 2466-2470

37 Kume, S., Muto, A., Aruga, J., Nakagawa, T., Michikawa, T., Furuichi, T., Nakade, S., Okano, H. and Mikoshiba, K. (1993) Cell 73, 555-570

38 Khan, A. A., Steiner, J. P., Klein, M. G., Schneider, M. F. and Snyder, S. H. (1992) Science 257, 815-818 